\title{
NEW RECORDS OF CLAUSILIIDAE (MOLLUSCA: GASTROPODA) IN THE DEMOCRATIC PEOPLE'S REPUBLIC OF KOREA WITH NOTES ON THEIR REPRODUCTIVE STRATEGY
}

\author{
EWA STWORZEWICZ ${ }^{1}$, ANNA SULIKOWSKA-DROZD ${ }^{2}$ \\ ${ }^{1}$ Institute of Systematics and Evolution of Animals, Polish Academy of Science, Sławkowska 17, \\ 31-016 Cracow, Poland (e-mail: stworzewicz@isez.pan.krakow.pl); \\ (1) https://orcid.org/0000-0003-0417-5193 \\ ${ }^{2}$ University of Lodz, Faculty of Biology and Environmental Protection, Department of Invertebrate \\ Zoology and Hydrobiology, Banacha 12/16, 90-237 Łódź, Poland (e-mail: anna.drozd@biol.uni.lodz.pl); \\ (1) https://orcid.org/0000-0002-2865-7130
}

ABSTRACT: The knowledge of clausiliid fauna of the northern part of Korean Peninsula (Democratic People's Republic of Korea) is still fragmentary. The field survey carried out by the Cracow Institute of Systematics and Evolution of Animals, Polish Academy of Sciences in 1971-1992 provided data on the occurrence of two species: Zaptyx stimpsoni miyanagai (Kuroda, 1936) and Tauphaedusa tau (O. Boettger, 1877) in this region. The specimens of the latter species contained embryonic shells, thus confirming its viviparity. For reproductive mode assessment we used $\mu$-CT scanning and 3D reconstructions.

KEY WORDS: land snails, Phaedusinae, viviparity, Korean Peninsula, micro-CT

\section{INTRODUCTION}

Clausiliid snails of the Far East (in traditional sense) are known from Japan, eastern China, Taiwan and the southern part of the Korean Peninsula (e.g. KWON 1990, 1993, MINATO 1994, NORDSIECK 1997, 1998, 2005). The Phaedusinae are the main group of the Far East Clausiliidae. Much information on the subfamily's systematics, shell and genital morphology is contained in NoRDSIECK's papers (1998, 2001, 2003, 2007). He also discussed the reproduction modes (oviparity or ovoviviparity) in a large number of taxa and its taxonomic significance.

Although the land snails of Korean Peninsula have been studied since the second half of the 20th century, there is little information from its northern part. MÖLLENDORFF (1887) published a list of 26 land snail species from Korean Peninsula, including two localities near the border of the northern part of Korea with Manchuria, but the five clausiliid species listed there (Clausilia aculus Benson 1842, C. tau O. Boettger 1877, C. gottschei Moellendorff 1887, C. claviformis Pffeifer 1850, C. belcheri Pffeifer 1850) were found only in the southern part of the peninsula or on Korean Archipelago. He did not collect gastropods personally, but he examined materials collected by Gottsche during his trip to Korea (GOTTSCHE 1886). Similarly, PILSBRY \& HirASE (1908a), based upon the same shell collection, described several new species of land snails from Fusan (southern part of Korean Peninsula), among them one clausiliid Euphaedusa fusaniana (as Clausilia fusaniana). The first survey of land snails of the whole Korean Peninsula was done by Kuroda (KURODA 1908, PILSBRY \& HIRASE 1908b, PILSBRY 1927). Kuroda explored the northern part of the peninsula and focussed on three areas: provinces Pyongan-pukdo, Pyongan-namdo and the border of Hvanghe-pukdo and Hvanghenamdo. Again, clausiliid snails were found only in the southern part of the peninsula and on the 
Quelpart Island. In 1939 Kuroda and Miyanaga mentioned Paganizaptyx miyanagai (Kuroda, 1936) from two localities: Sanbo and Kymgang-san Mts in the northern part of Korean peninsula. Hence, only one clausiliid species was probably recorded so far from the present territory of the Democratic People's Republic of Korea, including a record of this species in the list of land snails from DPRK (STWORZEWICZ 1997). To our knowledge, there are no other records of Clausiliidae from the territory of DPRK though the northern part of the peninsula was repeatedly subject to malacological field surveys (RIEDEL 1967, STWORZEWICZ 1997).

KWON (1993) listed five clausiliid taxa from the Republic of Korea: Euphaedusa aculus mokpoensis (Pilsbry et Hirase, 1909), E. fusaniana (Pilsbry et Hirase, 1908(a)), Reinia variegata (A. Adams, 1868), Paganizaptyx miyanagai (Kuroda, 1936), and P. miya- nagai ullungdoensis Kwon et Lee, 1991. According to NORDSIECK (2007) the last two taxa are subspecies of Hemiphaedusa (Hemizaptyx) stimpsoni (A. Adams, 1868). Because of the lack of the justification for this opinion Paganizaptyx miyanagai is still treated as a distinct species in the Korean literature (RED DATA BOOK 2012, LEE 2014, NATIONAL LIST 2015). LEE \& MiN (2002) listed an additional taxon from Korea: $E$. fusaniana uturyotoensis Kuroda et Hukuda, 1944. The taxa in the NATIONAL LIST (2015) include also E. aculus coreana (Möllendorff, 1887), Euphaedusa gottschei (Möllendorff, 1887) and Phaedusa sieboldii (Pfeiffer, 1848).

In this paper we present the first documented data on the occurrence of clausiliids in the northern part of the Korean Peninsula (Democratic People's Republic of Korea) together with data on their reproductive mode.

\section{MATERIAL AND METHODS}

Clausiliids were collected during four out of the 22 zoological expeditions to DPRK carried out within

the scientific exchange between the Cracow Institute of Systematics and Evolution of Animals, Polish

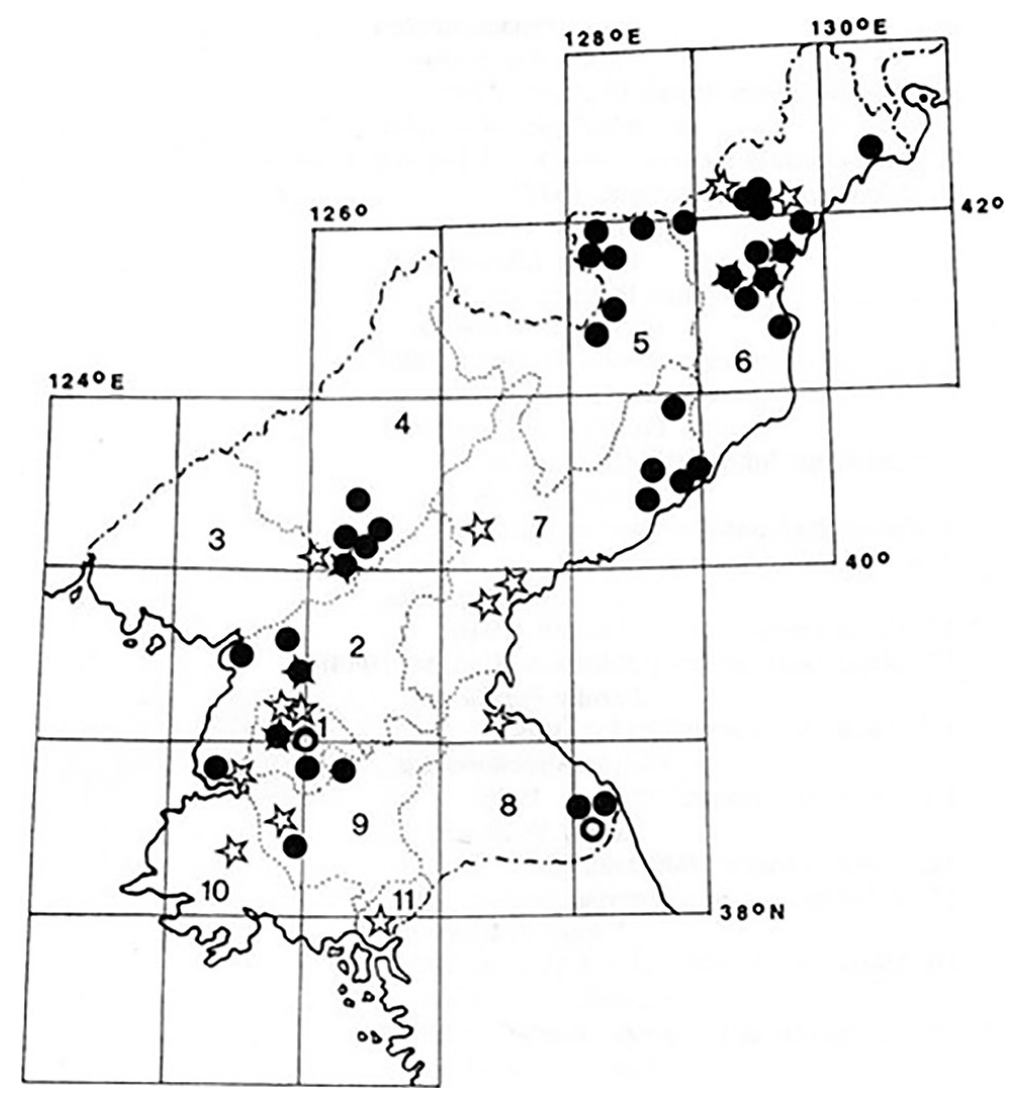

Fig. 1. Map of the northern part of Korean Peninsula (DPRK) with distribution of localities of the collected snails. 1-11 names of provinces: 1 - Pyongyang-si, 2 - Pyongan-namdo, 3 - Pyongan-pukto, 4 - Chagang-do, 5 - Ryanggang-do, 6 - Hamgyong-pukdo, 7- Hamgyong-namdo, 8 - Kangvon-do, 9 - Hwanghae-pukdo, 10 - Hwanghae-namdo, 11 Kesong-si; empty stars - material collected by RIEDEL, black circles - material collected by STWORZEWICZ, stars covered by black circles - materials collected by STWORZEWICZ and by RIEDEL, empty circles - clausiliid shells collected by STWORZEWICZ and by SZEPTYCKI (after STWORZEWICZ 1997, modified) 
Academy of Sciences and the Zoological Institute of Korean Academy of Sciences in Pyongyang in 19711992 (PAWŁOWSKI et al. 2000). Although malacological investigations were conducted in all the provinces of the country clausiliids were found only in two sites (Fig. 1): Kymgang-san (the Diamond Mountains) in Kangvon-do province - 38 $30^{\prime}-38^{\circ} 45^{\prime} \mathrm{N}$ and $128^{\circ} 00^{\prime}-128^{\circ} 20^{\prime}$ E (coll. A. SZEPTYCKI in 1981) and Ryongak-san (= Jongak-san), mountain in the suburbs of Pyongyang, ca.13 km west of the city centre, in Pyongyang-si province $-39^{\circ} 02^{\prime} \mathrm{N}, 125^{\circ} 34^{\prime} \mathrm{E}$ (coll. A. SZEPTYCKI in 1971 and 1974; E. STWORZEWICZ in 1991). Only empty shells of one species were found in each of the localities.

To assess the reproductive mode of the collected snails, we used computer microtomography $(\mu-\mathrm{CT})$ which makes it possible to check the presence of embryonic shells inside the parental shell, as well as to assess the development of apertural barriers and clausilium without shell destruction. The potential of this analytical tool was previously demonstrated

\section{RESULTS AND DISCUSSION}

Clausiliids collected in the Democratic People's Republic of Korea were identified as Zaptyx stimpsoni miyanagai (Kuroda, 1936) and Tauphaedusa tau (O. Boettger, 1877).

The first species was previously placed in Hemiphaedusa (Hemizaptyx) Pilsbry, 1905 (NORDSIECK 2007), or in Paganizaptyx Azuma, 1982 (LEE 2014). However, the latter genus is currently provisionally treated as a junior synonym of Zaptyx (sensu lato) (Motochin et al. 2017) "due to the poorly resolved phylogenetic status" and we follow this view. Zaptyx stimpsoni (A. Adams 1868) is a variable species with several subspecies described (NORDSIECK 2007) and should be regarded as a complex of species (R. UESHIMA, personal communication). From South Korea the subspecies Zaptyx stimpsoni miyanagai (Kuroda, 1936) was reported (KWON 1990).

In Kymgang-san, two shells of $Z$. stimpsoni miyanagai were collected from a moss-covered oak trunk. The dimensions of the individuals (one shell with broken apex and a hole on the back of the body whorl) are: shell height $11.3-11.72 \mathrm{~mm}$, shell width 2.86-3.1 mm, number of whorls 7.5, aperture height: $2.41 \mathrm{~mm}$, aperture width: $1.96 \mathrm{~mm}$. The upper and spiral lamellae are connected, the subcollumellar lamella does not reach the aperture margin. The principal palatal fold is long and well developed, the lunella is attached to the upper palatal fold and together they form the letter tau $(\tau)$. The $\mu$-CT examination revealed no embryos inside the shells (Figs 2-6). Although it is not the direct evidence of oviparity, the narrow shape of clausilium and the steeply using fossil and extant gastropods (e.g. MARXEN et al. 2008, AsHKENAZI et al. 2010, SULIKOWSKADROzD et al. 2014). In this kind of analysis negative results could not be automatically classified as oviparity, while the embryos recorded inside parental shell indicated the reproduction strategy involving long embryo retention or viviparity (=ovoviviparity sensu TOMPA 1979). The analyses were conducted in the X-ray Microtomography Laboratory, Department of Biomedical Computer Systems, Institute of Computer Science, University of Silesia. Scanning was performed with an XMT scanner (GE Sensing and Inspection Technologies, Phoenix $\mid X$-ray, Wunstorf, Germany) using the same setting: voltage $80 \mathrm{kV}$, current $90 \mu \mathrm{A}$, timing $250 \mathrm{~ms}, 1,000$ projections, rotation angle $360^{\circ}$, and voxel size $7.5 \mu \mathrm{m}$.

These data were used to reconstruct 3D images of shell interior. 3D models were created in cooperation with the Custom Medical Implants Laboratory in Lodz, equipped with software Amira v.5.5.0., FEI visualization Sciences Group Ltd., USA.

ascending lower lamella suggest this mode of reproduction (see NORDSIECK 2003).

Among the localities of $Z$. stimpsoni miyanagai in the Republic of Korea KWON (1990) lists also "Oekŭmgang", situated on the southernmost fringe of the Kymgang-san Mts., which extends up to the border of South Korea. The new locality of Z. stimpsoni miyanagai on the other side of the border (in DPRK) is the northernmost record from the Korean Peninsula. The next nearest locality of this species is known from Mt. Soyo in Gyeonggi-do (type locality), situated ca. $200 \mathrm{~km}$ to the south-west of the Kymgang-san (RED DATA BOOK 2012: 56-57). The remaining known sites are Sambang and Ullŭng Island (KWON 1990).

The second species, Tauphaedusa tau, (previously Tauphaedusa was treated as subgenus of Euphaedusa (NORDSIECK 2007)) was found in Ryongak-san, in 1971, 1974 and 1991. The southern slope of Ryongak Mountain is covered mainly with dry oak forest with pines, and shells (13 specimens) were collected on the ground around trunks of the old trees, among dry leaves and stones.

The dimensions of the individuals are: shell height - mean $13 \mathrm{~mm}$ (range 11.80-14.28), shell width $-3.0 \mathrm{~mm}$ (range 2.87-3.20), aperture height $2.7 \mathrm{~mm}(2.52-3.01)$, aperture width $-2.2 \mathrm{~mm}(2.06-$ 2.30 ), number of whorls - 9.5 (range 8.75-10.25).

Three individuals were examined by $\mu-\mathrm{CT}$; two of them contained single embryos (shell of 2-2.5 whorls) (Figs 7-13). Thus the viviparous reproduction of this snails is unquestionable, as in the previ- 
ously examined populations of Tauphaedusa tau from Honshu (SulikOWSKA-DROzD et al. 2018). The apertural barriers in these shells include a broad clausilium plate and the lower lamella spirally ascending, the superior and spiral lamella connected, the inner end of the lower lamella situated close to the inner end of the spiral lamella, the plica principalis long, the upper palatal fold connected to the lunella, forming a reversed Greek letter $\tau$, however the lunulla in some shells is very weak. The structure of apertural barriers of our individuals differ significantly from that of E. fusaniana which features a significant gap between the superior and spiral lamella. Taupheadusa tau is widespread in Japan and also introduced to the main- land China (Minato 1994, NoRdsieCK 2001). The phylogenetic relationships between T. tau and similar species T. gottschei described from Mokpo city situated in the south-western part of the Korean peninsula (MÖLlENDORFF 1887) and also found in Reisui, ca. $150 \mathrm{~km}$ east of Mokpo (KURODA \& MiYANAGA 1943) remain to be investigated in the future taxonomic revision of the genus.

Both Zaptyx stimpsoni miyanagai and Tauphaedusa tau seem to be very rare in North Korea. Despite the careful search in most of the provinces of DPRK, only a few empty shells were found. Z. stimpsoni miyanagai is regarded as an endemic Korean subspecies, and is placed in the RED DATA BOOK (2012).

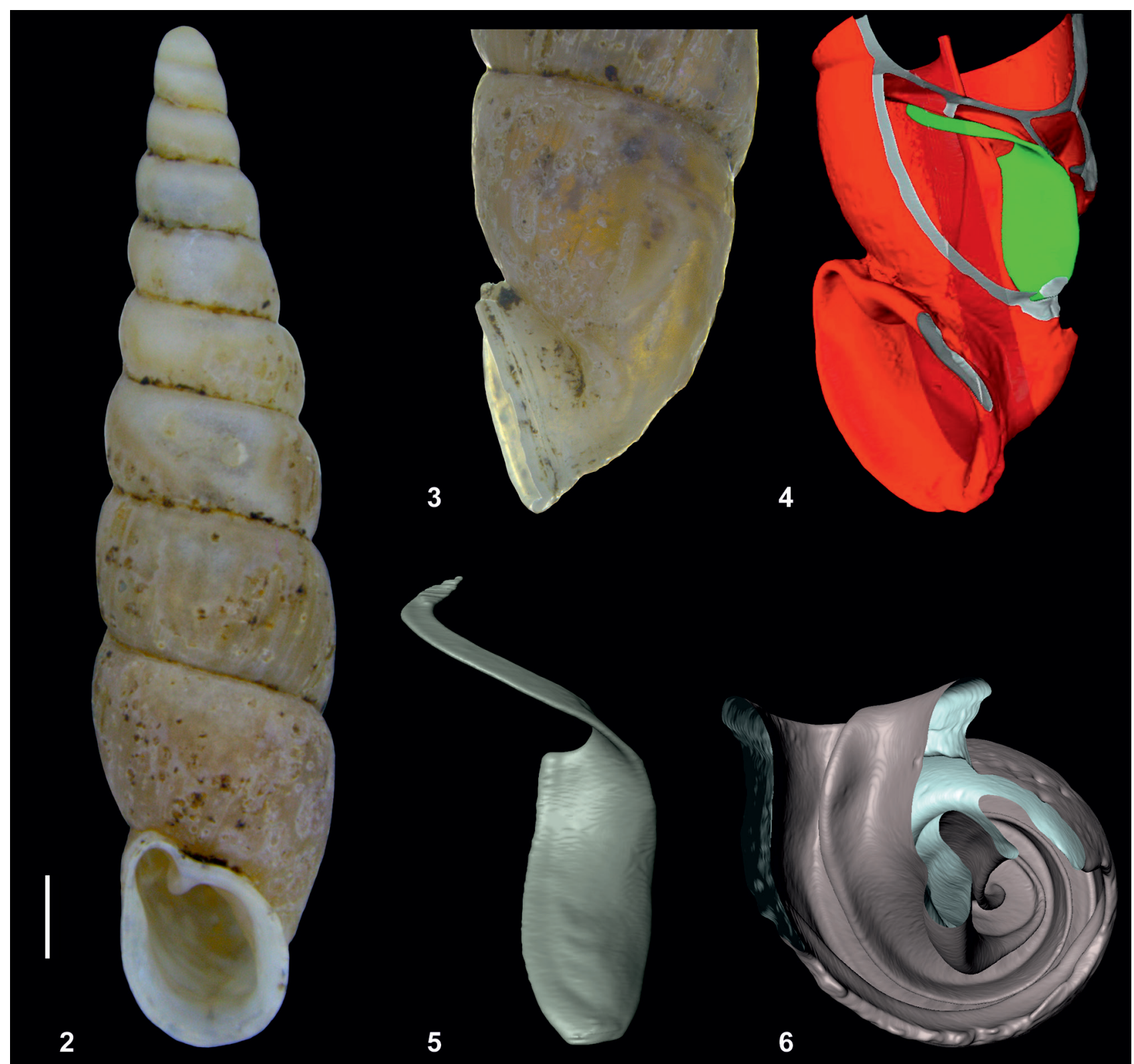

Figs 2-6. Zaptyx stimpsoni miyanagai (Kuroda, 1936) from Kymgang-san (the Diamond Mountains) in Kangvon-do province, North Korea: 2-3 - frontal and side view of the shell, 4-6- $\mu$-CT based reconstruction of shell: position of clausilium (4), clausilium (5), position of upper and spiral lamella (6). Scale bar (Fig. 2) $1 \mathrm{~mm}$ 
Our study contributes to the knowledge of the limits of their distribution in the continental Asia. land snail fauna of the North Korea. We report the lo- Acquiring $\mu$-CT images of shells allowed to identify calities of two clausiliid species close to the northern the reproductive mode of collected snails.

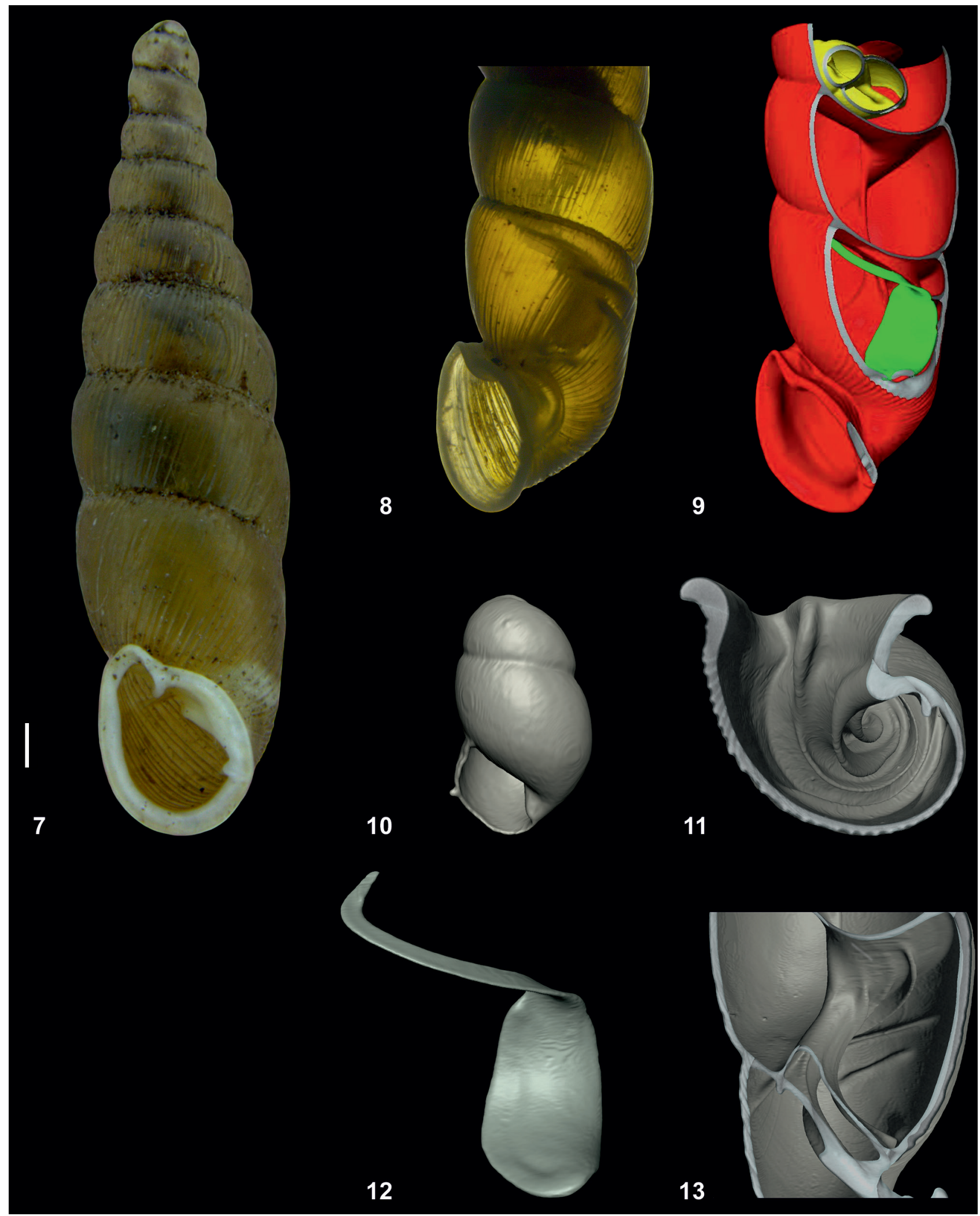

Figs 7-13. Tauphaedusa tau (O. Boettger, 1877) from Ryongak-san, Pyongyang-si province, North Korea: 7-8 - frontal and side view of the shell, 9-13 - $\mu$-CT based reconstruction of shell: position of embryo and clausilium (9), embryonic shell (10), upper and spiral lamella (11), clausilium (12), position of palatal plicae (13). Scale bar (Figs 7-9) $1 \mathrm{~mm}$ 


\section{ACKNOWLEDGEMENTS}

We are grateful to Mr. HARTMUT NORDSIECK for his advice concerning door-snails of Korean Peninsula and the introduction to the Senckenberg collection in Frankfurt a/Main. Our thanks go to dr PIOTR DUDA (Silesian University) for performing $\mu-C T$ scanning. This analysis was financed by the National Science Centre, Poland (project number 2016/21/B/NZ8/03086) granted to ASD.

\section{REFERENCES}

ASHKenAZI S., KlASS K., MiEnIS H. K., SPIRO B., ABEL R. 2010. Fossil embryos and adult Viviparidae from the Early-Middle Pleistocene of Gesher Benot Ya'aqov, Israel: ecology, longevity and fecundity. Lethaia 43: $\quad 116-127 . \quad$ https://doi.org/10.1111/j.15023931.2009.00178.x

GotTSCHE C. 1886. Land und Leute in Korea. Verhandlungen der Gesellschaft für Erdkunde zu Berlin 13: 245-262.

KURODA T. 1908. Collecting land shells in Quel Part Island. Conchological Magazine 2: 25-29.

KURODA T. 1936. Conchological news with preliminary reports of new species. Venus 6: 168-174.

Kuroda T., MiYanaga M. 1939. New land shells from northern Tyosen (Korea). Venus 9: 66-85.

Kuroda T., MiYAnAgA M. 1943. Notes on the land shells from Tyosen (Korea). Venus 12: 130-138.

KWON O. K. 1990. Mollusca (I). In: Ministry of Education Republic of Korea (ed.) Illustrated Encyclopedia of Fauna \& Flora of Korea, vol. 32.

KwON O. K. 1993. Coloured shells of Korea. Academy Publishing Company, Seoul.

LEE J. S. 2014. Endangered mollusks in the Republic of Korea. In: KIM S. B. (ed.) Korean Red List of Threatened Species, Second Edition. National Institute of Biological Resources, Incheon.

LEE J. S., MiN D. K. 2002. A catalogue of molluscan fauna in Korea. Korean Journal of Malacology 18: 93-217.

Marxen J. C., Prymak O., Beckmann F., Neues F., Epple M. 2008. Embryonic shell formation in the snail Biomphalaria glabrata: a comparison between scanning electron microscopy (SEM) and synchrotron radiation microcomputer tomography $(\mathrm{SR} \mu \mathrm{CT})$. Journal of Molluscan Studies 74: 19-26. https://doi.org/10.1093/ mollus/eym044

MinATO H. 1994. Taxonomy and distribution of the land snail family Clausiliidae (Gastropoda: Pulmonata) of Japan. Venus (Suppl. 2): 1-212.

Motochin R., WANG M., Ueshima R. 2017. Molecular phylogeny, frequent parallel evolution and new system of Japanese clausiliids land snails (Gastropoda: Stylommatophora). Zoological Journal of the Linnean Society 181: 795-845. https://doi.org/10.1093/zoolinnean/zlx023

MÖLlENDORFF O. F. VON 1887. Die Landschnecken von Korea. Jahrbücher der Deutschen Malakozoologischen Gesellschaft 14: 9-22.

NATIONAL LIST 2015. National list of species of Korea. Invertebrates. VI. Mollusks. Itd.
NORDSIECK H. 1997. Annotated check-list of the Taiwanese Phaedusinae (Gastropoda: Stylommatophora: Clausiliidae). Mittailungen der deutschen malakozoologische Geselschaft 60: 1-19.

NORDSIECK H. 1998. Critical revision of the system of the Japanese Phaedusinae, proposed by Minato (1994) (Gastropoda: Stylommatophora: Clausiliidae). Archiv für Molluskenkunde 127: 1-32. https://doi. org/10.1127/arch.moll/127/1998/21

NoRDSIECK H. 2001. Revision of the system of the Phaedusinae from mainland China with the description of new taxa (Gastropoda: Stylommatophora: Clausiliidae). Archiv für Molluskenkunde 129: 25-63. https://doi.org/10.1127/arch.moll/129/2001/25

NORDSIECK H. 2003. Systematic and nomenclatural notes on Phaedusinae with the description of new taxa (Gastropoda: Stylommatophora: Clausiliidae). Archiv für Molluskenkunde 132: 121-141. https://doi. org/10.1127/arch.moll/132/2003/121

NoRDSIECK H. 2005. New taxa of Phaedusinae and Garnieriinae from mainland China and Taiwan (Gastropoda: Stylommatophora: Clausiliidae). Archiv für Molluskenkunde 134: 23-52. https://doi. org/10.1127/arch.moll/0003-9284/134/023-052

NorDSIECK H. 2007. Worldwide door snails (Clausiliidae), recent and fossil. ConchBooks, Hackenheim.

PAWŁOWSKI J., STWORZEWICZ E., TOMEK T. 2000. Activity of the Cracow Institute of Systematics and Evolution of Animals of the Polish Academy of Sciences in zoological investigation of North Korean provinces. Bulletin of the Korean Association for Wildlife Conservation 2: 14-139.

PILSBRY H. A. 1927. Review of the land Mollusca of Korea. Proceedings of the Academy of Natural Sciences of Philadelphia 78(1926): 453-475.

Pilsbry H. A., HiRASE Y. 1908a. New land snails from Corea. The Conchological Magazine 2: 15-18.

PILSBRY H. A., HIRASE Y. 1908b. Land shells of Quelpart Island (Korea). The Conchological Magazine 2: 59-64.

RED DATA BOOK 2012. Red data book of endangered mollusks in Korea. National Institute of Biological Resources, Incheon.

RIEDEL A. 1967. Zonitidae (Gastropoda) aus Korea. Annales Zoologici 24: 361-366.

STWORZEWICZ E. 1997. The malacological investigations in North Korea. Fragmenta Faunistica 40: 293-298. https://doi.org/10.3161/00159301FF1997.40.26.293

SulikowsKa-Drozd A., Hirano T., WU S. P., PÁlLGERGELY B. 2018. High fecundity, rapid development 
and selfing ability in three species of viviparous land snails Phaedusinae (Gastropoda: Stylommatophora: Clausiliidae) from East Asia. Zoological Studies 57: 38 (1-11). https://doi.org/10.6620/ZS.2018.57-38

SULIKOWSKA-DROZD A., WALCZAK M., BINKOWSKI M 2014. Evolution of shell apertural barriers in viviparous land snails (Gastropoda: Pulmonata: Clausiliidae) Canadian Journal of Zoology 92: 205-213. https://doi. org/10.1139/cjz-2013-0222
TOMPA A. S. 1979. Oviparity, egg retention and ovoviviparity in Pulmonates. Journal of Molluscan Studies 45: 155-160. https://doi.org/10.1093/oxfordjournals.mollus.a065489

Received: October 19th, 2019

Revised: December 12th, 2019

Accepted: December 17th, 2019

Published on-line: February 21st, 2020 